\title{
PENGARUH JUMLAH TUMBUKAN PADA CAMPURAN ASPHALT CONCRETE WEARING COURSE (AC-WC) TAMBAHAN LATEKS TERHADAP SIFAT MARSHALL
}

\author{
Herman Fithra \\ Jurusan Teknik Sipil, Fakultas Teknik, Universitas Malikussaleh \\ email: hfithra@unimal.ac.id
}

\begin{abstract}
Abstrak
Salah satu fungsi dari lapisan Asphalt Concrete Wearing Course (AC-WC) adalah sebagai lapisan penutup (kedap air) untuk mencegah masuknya air kedalam campuran aspal, yang dapat merusak struktur aspal. Resapan air yang berasal dari limpasan air hujan maupun luapan air selokan dapat masuk kedalam aspal, bila lapisan permukaannya tidak sangat kedap. Oleh karenanya perlu campuran ACWC yang kedap air, yang dapat diperoleh dengan berbagai modifikasi. Salah satu modifikasi tersebut adalah tambahan lateks dalam campuran AC-WC. Penelitian ini bertujuan untuk mengetahui pengaruh dari jumlah tumbukan dengan tambahan bahan lateks terhadap campuran AC-WC dilihat dari sifat Marshall. Penelitian ini dilakukan dengan membuat rancangan benda uji standar di laboratorium, dilanjutkan dengan pencarian nilai Kadar Aspal Optimum (KAO). Nilai KAO ditambahkan lateks $2 \%$ dengan jumlah tumbukan $2 \times 75,2 \times 100,2 \times 125$ dan 2x150. Hasil dari jumlah tumbukan untuk benda uji tersebut dilakukan uji Marshall untuk mengetahui sifat Marshal. Hasil penelitian menunjukkan bahwa dengan jumlah tumbukan $2 \times 75,2 \times 100,2 \times 125$ dan 2x150 menghasilkan stabiltas berurutan sebesar $2027 \mathrm{~kg}, 1751 \mathrm{~kg}, 1672 \mathrm{~kg}$ dan $1760 \mathrm{~kg}$. Nilai flow yang dihasilkan beurutan sebesar 3,3 mm, 1,9 mm, 1,6 mm dan 1,3 mm. Hasil penelitian tersebut menujukkan bahwa dengan jumlah tumbukan lebih dari 2x75 semua benda uji campuran AC-WC dengan tambahan lateks 2\% dari KAO tidak memenuhi spesifikasi Bina Marga 2010.
\end{abstract}

Kata kunci: AC-WC, Stabilitas, Flow, Lateks, dan Marshall Test

\section{Pendahuluan}

Perkembangan rekayasa perkerasan jalan raya beberapa dekade terakhir sangatlah pesat. Salah satunya adalah penggunaan berbagai jenis bahan tambah pada campuran aspal beton (AC-WC) untuk meningkatkan kualitas campuran ataupun mempermudah proses pelaksanaan di lapangan. Campuran AC-WC digunakan sebagai lapisan penutup aspal (lapisan aus) sehingga diasumsikan tidak menerima beban repetisi roda kendaraan. AC-WC sebagai lapis penutup diharapkan tidak mengalami deformasi permanen dan tahan terhadap cuaca maupun perubahan lingkungan. AC-WC sebagai lapisan perkerasan lentur, dimana aspal berfungsi sebagai bahan pengikat agregat. Aspal dalam campuran AC-WC berkisar antara $4-10 \%$ berdasarkan berat dan $10-15 \%$ berdasarkan volume dari campuran agregat dan aspal. Sehingga kualitas aspal sangat menentukan keawetan dari suatu perkerasan lentur.

Penggunaan aspal pada perkerasan lentur AC-WC sangat sensitif, dimana jika kandungan aspal terlalu banyak maka perkerasan lentur AC-WC akan mengalami bleeding dan bila kadar aspal terlalu sedikit maka perkerasan lentur AC-WC akan mengalami retak-retak. Selain kadar aspal dalam campuran, banyaknya pori diantara butir-butir agregat yang diselimuti aspal (VITM) sangat 
menentukan keawetan perkerasan lentur AC-WC. VITM ini dibutuhkan untuk tempat bergesernya butir-butir agregat, akibat pemadatan tambahan yang terjadi oleh repetisi beban lalulintas, atau tempat jika aspal menjadi lunak akibat meningkatnya temperatur. VITM yang terlalu besar akan mengakibatkan perkerasan AC-WC berkurang kekedapan airnya (bersifat porous). Sehingga air dan udara muda memasuki rongga-rongga dalam campuran yang menyebabkan mudah teroksidasi dan akan mengurangi keawetannya atau berakibat meningkatnya proses oksidasi aspal yang dapat mempercepat penuaan aspal dan menurunkan sifat durabilitas perkerasan AC-WC. VITM yang terlalu kecil akan mengakibatkan perkerasan AC-WC mengalami bleeding jika temperatur meningkat, sehingga nilainya perlu ditetapkan dalam rentang waktu tertentu.

Kombinasi antara pengunaan aspal dan banyaknya pori yang tersedia dalam perkerasan AC-WC sangat dibutuhkan untuk menjaga keawetan perkerasan ACWC. Aspal yang berasal dari residu minyak bumi semakin hari semakin menipis persediaannya dengan harga yang cenderung terus naik, sehingga dibutuhkan bahan lain yang dapat menaikkan kualitas aspal dan perkerasan AC-WC. Pemadatan campuran AC-WC juga harus dapat diukur untuk mendapatkan banyaknya pori dalam perkerasan AC-WC selama umur pelayanan jalan.

Road Research Centre, Ministry of Public Work di Kuwait menyatakan penambahan 2\% lateks dan 5\% parutan ban bekas terhadap aspal dapat mencegah terjadinya retak-retak, bleeding dan memperkecil terjadinya pelepasan butir pada permukaan perkerasan lentur. Salah satu bahan tambah yang dapat digunakan dalam campuran AC-WC adalah elastomer alami/ lateks (Getah Karet). Bahan ini memberikan banyak keuntungan dalam kontruksi perkerasan jalan. Selain itu, lateks tersebut banyak dijumpai di Indonesia. Pemakaian lateks juga memiliki keuntungan diantaranya adalah penurunan penetrasi, peningkatan titik lembek dan peningkatan titik nyala. Penambahan lateks kedalam aspal dapat menurunkan kepekaan terhadap temperatur pada aspal dalam perkerasan AC-WC seiring penambahan lateks. Penambahan ini juga meningkatkan ketahanan terhadap kerusakan yang disebabkan oleh air karena interlocking antar agregat semakin baik.

Penelitian ini bertujuan untuk mengetahui pengaruh dari jumlah tumbukan dengan tambahan bahan lateks terhadap campuran AC-WC dilihat dari sifat Marshall, sehingga dapat memberikan hasil yang baik untuk perkerasan AC-WC dimasa yang akan datang. Mengingat lateks sangat murah dan mudah didapatkan di Indonesia.

\section{Tinjauan Kepustakaan}

Sjahdanulirwan, et.al., (2009) mengatakan bahwa aspal yang ideal adalah dapat memperbaiki atau meningkatkan sifat karakteristik campuran beraspal dan kemudahan kerja, yaitu aspal yang memiliki karakteristik sebagai berikut: (a) kekakuan rendah atau viskositas yang relatif tinggi sehingga tidak memerlukan temperatur tinggi untuk pemompaan aspal, pencampuran dan pemadatan, (b) kekakuan tinggi pada saat temperatur tinggi (musim panas) untuk menghindari alur dan sungkur, (c) kekakuan rendah pada saat temperatur rendah (musim hujan) untuk menghindari retak, (d) kelekatan terhadap agregat yang tinggi untuk menghindari pengelupasan. 


\subsection{Lateks (Getah Karet)}

Lateks adalah cairan getah yang didapat dari sadapan pohon karet (Hevea Brasiliensis). Lateks mempunyai sifat kenyal (elastis) sifat kenyal tersebut berhubungan dengan viskositas atau plastisitas karet.

\subsubsection{Karet Alam}

Karet alam ialah jenis karet pertama yang ditemukan oleh manusia. Setelah penemuan proses vulkanisasi sesuai dengan namanya, karet alam berasal dari alam yakni terbuat dari getah tanaman karet (Amiruddin, 2012).

Karet alam memiliki kelebihan diantaranya; daya elastisnya atau daya lentingnya sempurna; sangat plastis, sehingga mudah diolah; tidak mudah panas; tidak mudah retak. Jenis-jenis karet alam diantaranya; bahan olah karet (lateks kebun, sheet angin, slab tipis dan lump ); karet konvensional; lateks pekat; karet bongkah(block rubber); karet spesifikasi teknis (crumb rubber; karet siap olah (tyre rubber) dan karet reklim (reclaimed rubber).

\subsubsection{Efektifitas Aspal Karet dalam Campuran Beraspal Panas}

Besarnya efektifitas penambahan karet ke dalam aspal tergantung dari luas partikel karet yang didistribusi dalam aspal. Campuran sangat efektif jika semua partikel karet terdistribusi dengan baik di dalam aspal. Faktor lain yang mempengaruhi efektifitas campuran adalah jenis, jumlah dan ukuran partikel karet, besarnya temperatur dan lamanya pemanasan, interaksi antara karet dan aspal secara kimiawi serta jenis aspal. Karet dapat ditambahkan dalam aspal dalam berbagai bentuk, baik dalam bentuk cair, lembaran karet maupun dengan bubuk karet. Pemanasan pada temperatur tinggi sifat karet bisa menurun, untuk memperkecil terjadinya penurunan sifat temperatur yang disyaratkan adalah berkisar $150^{\circ} \mathrm{C}-160^{\circ} \mathrm{C}$ (Jernando et. al., 1983).

Hubungan aspal dengan karet dalam campuran aspal panas dapat dijelaskan sebagai berikut;

1. Interaksi antara Aspal dan Karet

Karet alam adalah termoplastik yang mengandung bahan dengan berat molekul yang sama dengan molekul dari fraksi aspal. Bila karet ditambahkan ke dalam aspal,s ebagian "fraksi ringan" aspal diserap ke dalam karet. Jika terdapat kesesuaian antara karet dan aspal, maka akan menghasilkan penambahan kekentalan dan elastisitas dari aspal. Perubahan sifat bahan pengikat aspal diatas, akan membuat perkerasan jalan beraspal lebih tahan terhadap deformasi dan retak. Karet seperti itu dan juga aspal dapat teroksidasi terutama pada temperatur tinggi. Perubahan ini terjadi pada sifat kimia dan fisik. Walaupun aspal karet lebih tahan terhadap oksidasi dibandingkan aspal atau karet saja, aspal karet tetap harus dilindungi dari proses oksidasi. Dalam hal ini aspal karet tidak boleh disimpan lama pada temperatur diatas $130^{\circ} \mathrm{C}$.

2. Ketahanan Terhadap Oksidasi

Semua aspal teroksidasi dan mengeras selama pencampuran, penghamparan dan selama masa pelayanan. Bila penetrasinya turun tajam dibawah kira-kira 30, maka perkerasan beraspal cenderung dapat menjadi retak. Tambahan karet ke dalam aspal mengurangi pengaruh tersebut. 
3. Ketahanan Terhadap Retak

Penambahan karet ke dalam aspal meningkatkan ketahanan terhadap retak. Lapisan campuran beraspal karet lebih mampu menahan retak refleksi daripada campuran beraspal tanpa karet. Bila semakin tua dan mengeras, maka campuran beraspal karet dapat menahan pengaruh oksidasi yang lebih baik dari pada campuran beraspal tanpa karet. Maka ketahanan retak campuran beraspal karet relatif lebih baik.

4. Kekakuan Struktur

Karet dapat meningkatkan kekakuan aspal tanpa membuatnya rapuh. Sehingga campuran beraspal karet memiliki kemampuan penyebaran yang lebih besar dalam rongga. Jika dua jalan dibangun dengan ketebalan yang sama, perkerasan aspal karet akan melendut lebih kecil akibat lalulintas dan akan diperkirakan berumur lebih lama dari pada menggunakan aspal tanpa karet.

\subsection{Penentuan Kadar Aspal Tengah $\left(\mathbf{P}_{\mathbf{b}}\right)$}

Pembuatan campuran benda uji diawali dengan menentukan kadar aspal tengah $\left(\mathrm{P}_{\mathrm{b}}\right)$, yang dapat dihitung berdasarkan persamaan berikut;

$$
\mathrm{Pb}=0,035(\% \mathrm{CA})+0,045(\% F A)+0,18(\% \text { filler })+K \quad \ldots \ldots
$$
dimana :

$\mathrm{P}_{\mathrm{b}} \quad=$ kadar aspal tengah, persen terhadap berat campuran

$\mathrm{CA}=$ persen agregat tertahan saringan No.8

FA $=$ persen agregat lolos saringan No.8 dan tertahan saringan No. 200

Filler $=$ persen agregat minimal $75 \%$ lolos No. 200

$\mathrm{K}=$ konstanta $1-2$

Kadar aspal tengah merupakan pedoman untuk membuat benda uji agar diperoleh kadar aspal optimum (KAO) pada suatu campuran aspal beton. Nilai kadar aspal tengah yang diperoleh dari perhitungan, selanjutnya dibulatkan untuk memudahkan menentukan kadar aspal dalam campuran aspal beton. Kinerja dari beton aspal padat dapat ditentukan melalui pengujian benda uji di laboratorium berdasarkan parameter Marshall yang meliputi stabilitas, flow dan $M Q$ serta volumetrik aspal meliputi density, VMA, VITM dan VFWA.

\subsection{Kerapatan (density)}

Density merupakan tingkat kerapatan campuran beton aspal setelah campuran beton aspal dipadatkan. Nilai density biasanya digunakan untuk membandingkan nilai kepadatan rata-rata lapisan yang telah selesai di lapangan dengan kepadatan di laboratorium yang biasanya $\geq 96 \%$. Kerapatan ini dipengaruhi oleh temperatur pemadatan, jumlah tumbukan, kadar aspal, kualitas dan jenis fraksi agregat penyusun campuran beton aspal. Besarnya kerapatan dapat dihitung dengan menggunakan persamaan berikut:

$$
\text { Density }=\frac{\text { berat kering bemia uji }(g r)}{\text { Volume bende } u j i(\mathrm{~cm} 3)}
$$

\subsection{Stabilitas (Stability)}

Stabilitas dinyatakan dalam kilogram, pengujian nilai stabilitas adalah kemampuan maksimum beton aspal padat menerima beban sampai terjadi kelelehan plastis. Stabilitas merupakan kemampuan lapis perkerasan untuk 
menahan beban lalulintas tanpa mengalami deformasi atau perubahan bentuk permanen (permanent deformation). Nilai stabilitas dipengaruhi oleh bentuk butir, kualitas, tekstur permukaan, gradasi agregat yaitu pada gesekan antar butiran agregat dan penguncian antar butir agregat, daya lekat, dan kadar aspal dalam campuran. Nilai stabilitas diperoleh langsung dari pembacaan arloji stabilitas pada alat uji Marshall.

Nilai stabilitas $(\mathrm{kg})=$ nilai pembacaan arloji stabilitas $\mathrm{x}$ kalibrasi proving ring $\mathrm{x}$ koreksi tebal benda uji

\subsection{Kelelehan (flow)}

Flow adalah besarnya perubahan bentuk plastis dari beton aspal padat akibat adanya beban sampai batas keruntuhan. Besarnya nilai flow diperoleh dari pembacaan arloji flowmeter saat melakukan pengujian Marshall.

Nilai flow = nilai pembacaan arloji flow pada pengujian Marshall dengan satuannya milimeter $(\mathrm{mm})$

\subsection{Perhitungan Marshall Quotient (MQ)}

Marshall Quotient adalah perbandingan antara nilai stabilitas dan flow, yang dipakai sebagai pendekatan terhadap tingkat kekakuan campuran. Besarnya nilai Marshall Quotient $(M Q)$ dapat dihitung dengan menggunakan persamaan berikut;

$$
M Q=\frac{\text { nilai grabilitas (kg) }}{\text { nilai flow (mm) }}
$$

\section{Metode Penelitian}

Penelitian dimulai dengan melakukan kajian pustaka, kegiatan di laboratorium, analisa data dan kesimpulan. Kegiatan terbesar yang dilaksanakan dalam penelitian ini adalah kegiatan laboratorium, terbagi atas tiga kegiatan utama, yaitu pengujian properties material, perancangan campuran (mix design) dengan metoda Marshall dan pemeriksaan karakteristik campuran aspal panas AC-WC dengan tambahan lateks $2 \%$ dan variasi tumbukan $2 \times 75 ; 2 \times 100,2 \times 125$ dan $2 \times 150$.

\subsection{Sifat Aspal dan Agregat}

Aspal yang digunakan adalah jenis aspal keras AC 60/70 produksi Pertamina. Pengujian yang dilakukan meliputi: penetrasi aspal, berat jenis aspal, titik lembek, titik nyala, kehilangan berat dengan, kelarutan aspal, daktilitas dan penetrasi setelah kehilangan berat. Pengujian agregat menggunakan spesifikasi dari SNI dan AASHTO. Jenis pengujian yang dilakukan beserta spesifikasi yang digunakan adalah analisa saringan, berat jenis dan penyerapan agregat kasar, berat jenis dan penyerapan agregat halus, keausan agregat, pelapukan agregat dan kelekatan terhadap aspal.

\subsection{Perancangan Benda Uji (mix design) Metoda Marshall}

Metoda Marshall digunakan untuk menganalisis stabilitas, flow, Marshall Qoutient, dan analisis volumetrik. Pada metoda ini, persiapan, analisis, dan pengujian yang disesuaikan dengan prosedur Marshall. Untuk mendapatkan kadar aspal optimum (KAO) disiapkan benda uji dengan variasi kadar aspal 4,0\% 
sampai $6,0 \%$ dengan interval $0,5 \%$ dari total berat agregat. Tabel 1 berikut memperlihatkan jumlah benda uji yang dibuat.

Tabel 1 Jumlah Benda Uji

\begin{tabular}{|c|c|c|c|c|c|c|}
\hline \multirow{2}{*}{ Benda uji } & \multicolumn{7}{|c|}{ Kadar Aspal Tengah $(\mathrm{Pb})$} & \multirow{2}{*}{$\begin{array}{c}\text { Total } \\
\text { Benda Uji }\end{array}$} \\
\cline { 2 - 6 } & -1 & $-0,5$ & 0 & $+0,5$ & +1 & 15 \\
\hline Jumlah & 3 & 3 & 3 & 3 & 3 & \multirow{7}{*}{$\begin{array}{c}\text { Total Benda } \\
\text { Uji }\end{array}$} \\
\hline \multirow{7}{*}{ Benda uji } & \multicolumn{7}{|c|}{ KAO + Kadar Lateks $2 \%$} & 12 \\
\cline { 2 - 5 } & $2 \times 75 \mathrm{~T}$ & $2 \times 100 \mathrm{~T}$ & $2 \times 125 \mathrm{~T}$ & $2 \times 150 \mathrm{~T}$ & 3 & 12 \\
\hline Jumlah & 3 & 3 & 3 & 3 & 3 \\
\hline
\end{tabular}

Perancangan benda uji AC-WC harus menghasilkan campuran yang baik, maka dipakai gradasi menerus dan rapat seperti disyaratkan dalam spesifikasi Bina Marga 2010.

Tabel 2 Target Gradasi Agregat AC-WC

\begin{tabular}{|c|c|c|c|c|c|c|c|}
\hline \multicolumn{2}{|c|}{ Saringan } & \multirow{2}{*}{\multicolumn{2}{|c|}{$\begin{array}{c}\text { Spesifikasi Umum } \\
\text { Bina Marga (2010) } \\
\% \text { lolos }\end{array}$}} & \multicolumn{4}{|c|}{ Data Pengujian } \\
\hline \multirow{2}{*}{$\begin{array}{l}\text { Metrik } \\
(\mathrm{mm})\end{array}$} & \multirow[b]{2}{*}{ ASTM } & & & \multirow{2}{*}{$\begin{array}{l}\text { Lolos } \\
(\%)\end{array}$} & \multirow{2}{*}{$\begin{array}{c}\text { Tertahan } \\
(\%)\end{array}$} & \multirow{2}{*}{$\begin{array}{c}\text { Total } \\
(\%)\end{array}$} & \multirow{2}{*}{$\begin{array}{c}\text { Berat per } \\
\text { Benda Uji } \\
\quad \text { (gram) }\end{array}$} \\
\hline & & $\begin{array}{c}\text { Titik } \\
\text { Kontrol }\end{array}$ & $\begin{array}{c}\text { Daerah } \\
\text { Larangan }\end{array}$ & & & & \\
\hline 25 & 1" & - & & & - & \multirow{6}{*}{62,85} & - \\
\hline 19 & $3 / 4 "$ & 100 & & 100 & 3,31 & & 39,7 \\
\hline 12,5 & $1 / 2 "$ & $90-100$ & & 96,69 & 9,21 & & 110,5 \\
\hline 9,5 & $3 / 8 "$ & $72-90$ & & 87,49 & 21,24 & & 254,8 \\
\hline 4,75 & No.4 & $54-69$ & & 66,25 & 18,26 & & 219,2 \\
\hline 2,36 & No.8 & $39,1-53$ & 39,1 & 47,99 & 10,83 & & 130 \\
\hline 1,19 & No.16 & $31,6-40$ & $25,6-31,6$ & 37,16 & 12,68 & \multirow{4}{*}{32,91} & 152,2 \\
\hline 0,6 & No.30 & $23,1-30$ & $19,1-23,1$ & 24,47 & 7,38 & & 88,6 \\
\hline 0,3 & No.50 & $15,5-22$ & 15,5 & 17,09 & 7,71 & & 92,56 \\
\hline 0,149 & No.100 & $9-15$ & & 9,38 & 5,14 & & 61,64 \\
\hline 0,075 & No.200 & $4-10$ & & 4,24 & 4,24 & 4,24 & 50,9 \\
\hline \multicolumn{6}{|c|}{ Total } & 100 & 1200 \\
\hline
\end{tabular}

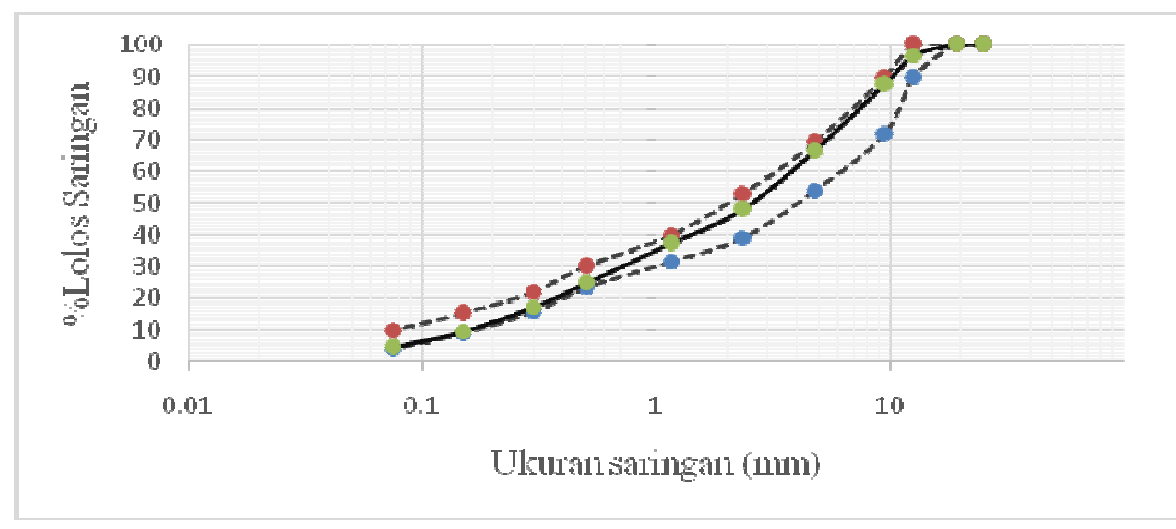

Gambar 1 Grafik Campuran AC-WC

Pengaruh Jumlah Tumbukan Pada Campuran Asphalt Concrete Wearing Course (ACWC) Tambahan Lateks Terhadap Sifat Marshall - Herman Fithra 


\section{Hasil dan Pembahasan}

4.1 Pengujian Material untuk Campuran AC-WC

Hasil pengujian terhadap material untuk AC-WC dengan tambahan lateks $2 \%$ seperti Tabel 3 sampai dengan Tabel 4 berikut.

Tabel 3 Hasil Pemeriksaan Aspal AC 60/70

\begin{tabular}{|c|l|c|c|c|c|}
\hline \multirow{2}{*}{ No. } & \multicolumn{1}{|c|}{ Sifat Aspal } & \multicolumn{2}{|c|}{ Persyaratan } & \multirow{2}{*}{ Hasil } & \multirow{2}{*}{ Satuan } \\
\cline { 3 - 5 } & & Min & Mak & & \\
\hline 1 & Penetrasi $25^{\circ} \mathrm{C}(5$ detik $)$ & 60 & 79 & 67,2 & $0,1 \mathrm{~mm}$ \\
\hline 2 & Titik lembek $($ ring \& ball $)$ & 45 & 58 & 50,3 & ${ }^{\circ} \mathrm{C}$ \\
\hline 3 & Titik nyala $($ clev. Open cup $)$ & 200 & - & 341 & ${ }^{\circ} \mathrm{C}$ \\
\hline 4 & Kelarutan $\left(\mathrm{CCL}_{4}\right)$ & 99 & - & 99,77 & $\%$ berat \\
\hline 5 & Daktalitas $25^{\circ} \mathrm{C}(5 \mathrm{~cm} /$ menit $)$ & 100 & - & $>100$ & $\mathrm{~cm}$ \\
\hline 6 & Berat jenis $\left(25^{\circ} \mathrm{C}\right)$ & 1 & - & 1,040 & - \\
\hline
\end{tabular}

Agregat yang merupakan bahan utama dari AC-WC yang berasal dari Krueng Mane - Kabupaten Bireuen. Hasil pemeriksaan agregat seperti pada tabel berikut;

Tabel 4 Hasil Pemeriksaan Agregat

\begin{tabular}{|c|c|c|c|c|c|}
\hline \multirow{2}{*}{ No. } & \multirow{2}{*}{ Sifat Agregat } & \multicolumn{2}{|c|}{ Persyaratan } & \multirow{2}{*}{ Hasil } & \multirow{2}{*}{ Satuan } \\
\hline & & Min & Maks & & \\
\hline \multicolumn{6}{|c|}{ Agregat Kasar } \\
\hline 1 & Keausan pada 500 putaran & - & 40 & 33,9 & $\%$ \\
\hline 2 & Penyerapan air & - & 3 & 1,982 & $\%$ \\
\hline 3 & Berat jenis curah (bulk) & 2,5 & - & 2,541 & - \\
\hline 4 & Berat jenis semu & 2,5 & - & 2,677 & - \\
\hline \multicolumn{6}{|c|}{ Agregat Halus } \\
\hline 1 & Penyerapan air & - & 3 & 0,010 & $\%$ \\
\hline 2 & Berat jenis curah (bulk) & 2,5 & - & 2,533 & - \\
\hline 3 & Berat jenis semu & 2,5 & - & 2,597 & - \\
\hline 4 & Sand equivalent & 40 & - & 79,66 & $\%$ \\
\hline \multicolumn{6}{|c|}{ Filler } \\
\hline 1 & Berat jenis & 2,5 & - & 2,697 & - \\
\hline
\end{tabular}

\subsection{Pengujian Marshall (mix design) dan volumetrik}

Hasil pengujian karakteristik Marshall dari benda uji dengan KAO 5,5\% + $2 \%$ lateks dengan variasi tumbukan $2 \times 75,2 \times 100,2 \times 125$ dan $2 \times 150$ sebagai berikut.

Tabel 5 Hasil Pengujian Marshall dengan Variasi Tumbukan

\begin{tabular}{|c|c|c|c|c|c|c|c|c|}
\hline \multirow[t]{2}{*}{ No } & \multirow{2}{*}{$\begin{array}{c}\text { Kadar } \\
\text { aspal }\end{array}$} & \multirow{2}{*}{$\begin{array}{c}\text { Parameter } \\
\text { Marshall }\end{array}$} & \multirow[t]{2}{*}{ Satuan } & \multirow[b]{2}{*}{ Spesifikasi } & \multicolumn{4}{|c|}{ variasi tumbukan } \\
\hline & & & & & $2 \times 75$ & $2 \times 100$ & $2 \times 125$ & $2 \times 150$ \\
\hline 1 & \multirow{7}{*}{$\begin{array}{c}5,5 \% \\
+ \\
2 \% \\
\text { Lateks }\end{array}$} & Density & $\mathrm{gr} / \mathrm{cm}^{3}$ & - & 2,268 & 2,273 & 2,294 & 2,295 \\
\hline 2 & & VMA & $\%$ & Min 15 & 15,262 & 15,064 & 14,283 & 14,240 \\
\hline 3 & & VIM & $\%$ & $4,0-6,0$ & 5,330 & 5,109 & 4,236 & 4,189 \\
\hline 4 & & VFA & $\%$ & $\min 65$ & 65,094 & 66,339 & 70,358 & 70,694 \\
\hline 5 & & Stabilitas & $\mathrm{Kg}$ & $\min 800$ & 2027 & 1751,8 & 1672,3 & 1760,4 \\
\hline 6 & & Flow & $\mathrm{Mm}$ & $\min 3$ & 3,317 & 1,950 & 1,637 & 1,333 \\
\hline 7 & & MQ & $\mathrm{kg} / \mathrm{mm}$ & $\min 250$ & 656,6 & 936 & 1021 & 1341,9 \\
\hline
\end{tabular}

Pengaruh Jumlah Tumbukan Pada Campuran Asphalt Concrete Wearing Course (ACWC) Tambahan Lateks Terhadap Sifat Marshall - Herman Fithra 


\subsection{Pembahasan}

\subsubsection{Kadar Aspal Optimum (KAO)}

KAO pada campuran adalah kondisi di mana suatu campuran dengan jumlah kadar aspal tertentu mempunyai karakteristik Marshall yang memenuhi persyaratan campuran dan memiliki nilai karakteristik yang paling optimum. Berdasar metode narrow range Asphalt Institute, (1993) nilai-nilai kadar aspal untuk setiap parameter diplotkan dalam bar chart didapat rentang kadar aspal yang memenuhi persyaratan teknik, dengan pertimbangan densifikasi akibat beban lalu lintas, cukup menyediakan rongga bila terjadi densifikasi dan pemuaian aspal akibat meningkatnya temperatur, nilai kadar aspal optimum (KAO) ditetapkan sebesar 5,5\% terhadap total agregat.

\subsubsection{Nilai Density, VITM, VFWA, Stability dan MQ}

Campuran AC-WC dengan KAO 5,5\% dan tambahan lateks 2\% dengan jumlah tumbukan $2 \times 75,2 \times 100,2 \times 125$ dan $2 \times 150$ menunjukkan hasil dari density, VITM, VFWA, Stability dan MQ sesuai dengan spesifikasi Bina Marga 2010. Pada tumbukan 2x150 menunjukkan semakin besar persentase aspal yang mengikat butir-butir agregat dengan film aspal yang lebih tebal. Sehingga campuran AC-WC ini lebih kedap air, tetapi nilai VMA dan flow tidak memenuhi spesifikasi. Campuran AC-WC dengan tumbukan 2x100, 2x125 dan 2x150 tidak dapat dipakai untuk perkerasan aspal beton.

\subsubsection{Nilai Flow}

Hasil pengujian flow dengan alat Marshall terhadap benda uji dengan variasi tumbukan 2x75 menunjukkan hasil 3,32 $\mathrm{mm}(>3 \mathrm{~mm})$ memenuhi spesifikasi Bina Marga 2010. Sementara untuk variasi tumbukan 2x100, 2x125 dan 2x150 menunjukkan hasil yang tidak memenuhi spesifikasi Bina Marga 2010. Hasil pengujian flow ditampilkan dalam Gambar 2 berikut.

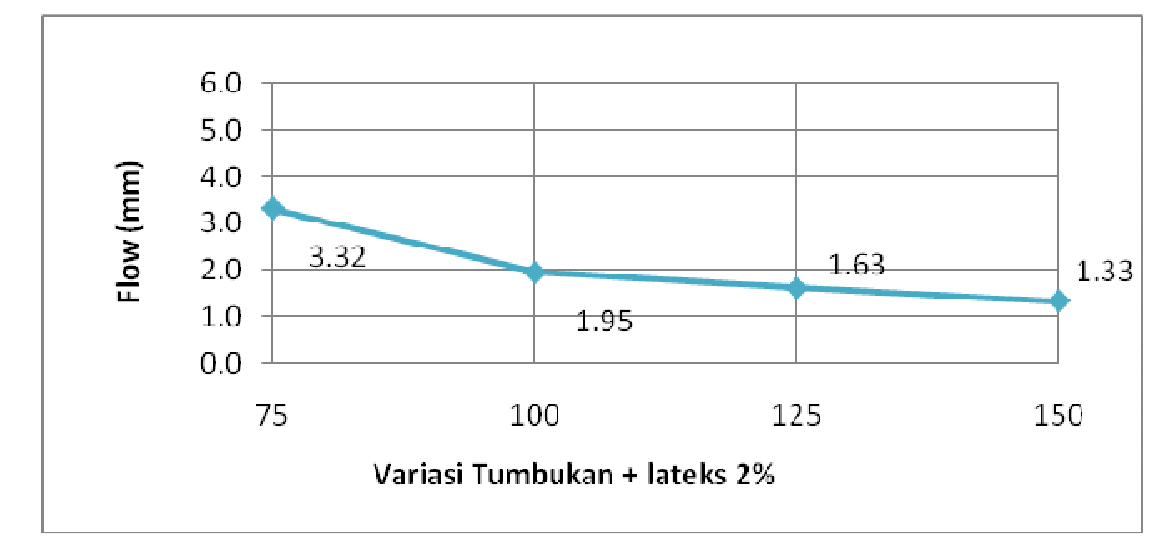

Gambar 2 Grafik Hubungan Variasi Tumbukan Terhadap Nilai Flow

Flow adalah besarnya perubahan bentuk plastis dari beton aspal padat akibat adanya beban sampai batas keruntuhan. Nilai flow dipengaruhi oleh kadar aspal, viskositas aspal, gradasi agregat, jumlah tumbukan dan temperatur pemadatan. Besarnya nilai flow diperoleh dari pembacaan arloji flowmeter saat melakukan pengujian Marshall. 
Campuran AC-WC yang dipadatkan dengan tumbukan 2x100, 2x125 dan 2x150 menjadikan campuran sangat rapuh. Hal ini disebabkan tidak tersediannya lagi pori dalam campuran agregat sebagai akibat campuran yang sangat padat. Pengaruh dari campuran yang sangat padat ini tidak memberikan ruang bagi aspal untuk mengisi rongga, sehingga terjadi bleeding. Bleeding menjadi pelicin dalam campuran AC-WC mengakibatkan terjadinya perubahan bentuk plastis yang lebih cepat.

\subsubsection{Nilai VMA}

Hasil perhitungan volumetrik terhadap VMA terhadap benda uji dengan variasi tumbukan 2x75 dan 2x100 menunjukkan hasil 15,262 dn 15,064 mm (>15 $\mathrm{mm}$ ) memenuhi spesifikasi Bina Marga 2010. Sementara untuk variasi tumbukan 2x125 dan 2x150 menunjukkan hasil yang tidak memenuhi spesifikasi Bina Marga 2010. Hasil pengujian flow ditampilkan dalam Gambar 3 berikut.

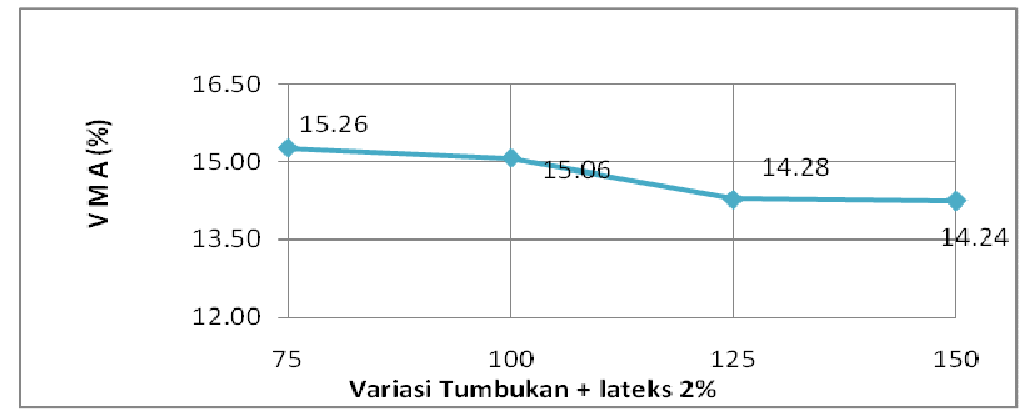

Gambar 3 Grafik Hubungan Variasi Tumbukan Terhadap Nilai VMA

Volume pori dalam agregat campuran $(V M A=$ voids in the mineral aggregate) adalah banyaknya pori diantara butir-butir agregat dalam beton aspal padat atau volume pori dalam beton aspal padat jika seluruh selimut aspal ditiadakan. VMA akan meningkat jika selimut aspal lebih tebal, atau agregat yang digunakan bergradasi terbuka, dari gambar 4.2 terlihat bahwa nilai VMA pada campuran AC-WC terus turun seiring bertambahnya jumlah tumbukan. Turunnya nilai VMA ini disebabkan oleh jumlah tumbukan pada benda uji. Akibat dari tumbukan ini agregat dan aspal terus mengisi rongga-rongga yang ada, diantara pori-pori yang ditinggalkan oleh ikatan antar agregat. Sehingga semakin padat campuran akan semakin sedikit rongga yang tersisa.

\section{Kesimpulan dan Saran}

\subsection{Kesimpulan}

Berdasarkan dari hasil penelitian dan pembahasan yang telah dilakukan maka dapat diambil beberapa kesimpulan sebagai berikut :

1. Campuran $\mathrm{AC}-\mathrm{WC}$ dengan $\mathrm{KAO} 5,5 \%$ dan tambahan lateks $2 \%$ yang memenuhi spesifikasi Bina Marga 2010 hanya dengan tumbukan 2x75;

2. Campuran AC-WC dengan tumbukan $>2 \times 75$ menyebabkan kadar rongga dalam campuran agregat dibawah $15 \%$, hal ini menyebabkan campuran sangat rapuh;

3. Campuran AC-WC dengan tumbukan $>2 \times 75$ menyebabkan nilai kelelehan menjadi sangat kecil, dibawah $3 \mathrm{~mm}$. 


\subsection{Saran}

Berdasarkan hasil penelitian dapat diberikan saran-saran sebagai rekomendasi berupa :

1. Adanya penelitian lanjutan dengan campuran AC-WC dengan $\mathrm{KAO} 5,5 \%$ dan tambahan lateks $2 \%$ dengan tumbukan $<2 \times 75$;

2. Perlunya penelitian lanjutan dengan campuran AC-WC dengan kadar aspal $4 \%$ dan tambahan lateks $2 \%$ dengan tumbukan variasi 2x50; 2x75 dan 2x100.

\section{Ucapan Terima Kasih}

Ucapan terima kasih disampaikan kepada saudara Syahri dan kawan-kawan yang melakukan penelitian serta para teknisi laboratorium jurusan Teknik Sipil Universitas Malikussaleh dan semua pihak yang telah memberi dukungan hingga penelitian dan tulisan ini selesai dibuat.

\section{Daftar Kepustakaan}

Amiruddin, dkk, 2012, Studi Penambahan Aditif Lateks Terhadap Karakteristik Campuran Aspal Hot Roller Sheet - Wearing Course (HRS-WC),

Prosiding pada Konferensi Nasional Teknik Sipil VI, Universitas Trisakti, Jakarta.

Anonim, 2010, Spesifikasi Umum, Depatemen Pekerjaan Umum, Direktorat Jendral Bina Marga, Jakarta.

Asphalt Institute, 1997, Mix Desig Methodes For Asphalt Concrete and Other Hot-Mix Types, Manual Series No.2 (MS-2), Sixth Edition, Lexington, Kentucky, USA.

Fithra, 2011, Karakteristik Penggunaan Serbuk Ban Bekas Pada Campuran Panas Asphalt Concrete Binder Course (AC-BC), Jurnal Teras Vol.1 Nomor 2, halaman 145-154 ISSN 2088-0561, Jurusan Teknik Sipil Fakultas Teknik Universitas Malikussaleh.

Fithra, 2010, Pengaruh Penggunaan Serbuk Ban Karet sebagai Pengganti Agregat halus pada Campuran Aspal (HRS-WC), Jurnal Teras Vol.8 Nomor 1, halaman 1693-4105 ISSN 2088-0561, Jurusan Teknik Sipil Fakultas Teknik Universitas Malikussaleh.

Fithra, 2009, Pengaruh Perbedaan Spesifikasi dan Gradasi Terhadap Durabilitas Perkerasan Campuran Panas AC-WC dan HRS-WC, Proceedings of The 3th International Conference on Development of Aceh (ICDA-3), pp.188 - 207, Universitas Malikussaleh, Aceh Utara, Aceh.

Fithra, 2008, Pengaruh Rendaman Air laut Terhadap Durabilitas Beton Aspal

Campuran Panas, Jurnal Samudra Vol.2 Nomor 1, Mei 2008, LPPM, Universitas Malikussaleh.

Sjahdanulirwan, 2009, Kelebihan Serta kekurangan Perkerasan Beraspal dan

Beton, Jurnal Jalan dan Jembatan, Penerbit Puslitbang Jalan dan Jembatan, Bandung. 